\title{
Identification and localization of the structural proteins of anguillid herpesvirus 1
}

\author{
Steven J van Beurden ${ }^{1,2^{*}}$, Baptiste Leroy ${ }^{3}$, Ruddy Wattiez ${ }^{3}$, Olga LM Haenen ${ }^{1}$, Sjef Boeren ${ }^{4}$, Jacques JM Vervoort ${ }^{4}$,
} Ben PH Peeters ${ }^{1}$, Peter JM Rottier ${ }^{2}$, Marc Y Engelsma ${ }^{1}$ and Alain F Vanderplasschen ${ }^{5}$

\begin{abstract}
Many of the known fish herpesviruses have important aquaculture species as their natural host, and may cause serious disease and mortality. Anguillid herpesvirus 1 (AngHV-1) causes a hemorrhagic disease in European eel, Anguilla anguilla. Despite their importance, fundamental molecular knowledge on fish herpesviruses is still limited. In this study we describe the identification and localization of the structural proteins of AngHV-1. Purified virions were fractionated into a capsid-tegument and an envelope fraction, and premature capsids were isolated from infected cells. Proteins were extracted by different methods and identified by mass spectrometry. A total of 40 structural proteins were identified, of which 7 could be assigned to the capsid, 11 to the envelope, and 22 to the tegument. The identification and localization of these proteins allowed functional predictions. Our findings include the identification of the putative capsid triplex protein 1, the predominant tegument protein, and the major antigenic envelope proteins. Eighteen of the $40 \mathrm{AngHV}-1$ structural proteins had sequence homologues in related Cyprinid herpesvirus 3 (CyHV-3). Conservation of fish herpesvirus structural genes seemed to be high for the capsid proteins, limited for the tegument proteins, and low for the envelope proteins. The identification and localization of the structural proteins of AngHV-1 in this study adds to the fundamental knowledge of members of the Alloherpesviridae family, especially of the Cyprinivirus genus.
\end{abstract}

\section{Introduction}

The Alloherpesviridae family, belonging to the Herpesvirales order comprises all bony fish and amphibian herpesviruses [1]. Currently, the family contains 4 genera with 11 species [2]. At least another 17 herpesviruses infecting bony fish have been described, but have not yet been sufficiently characterized to allow classification $[1,3,4]$. Many of these viruses cause serious disease and mortality in their respective host species, many of which are important aquaculture species. For example, channel catfish virus or Ictalurid herpesvirus 1 (IcHV-1) may cause up to $100 \%$ mortality in channel catfish (Ictalurus punctatus) fingerlings, which posed a significant problem in the big catfish aquaculture industry in the United States [5]. Koi herpesvirus or Cyprinid herpesvirus 3 $(\mathrm{CyHV}-3)$ is another highly contagious and virulent disease in its host species common carp and koi (Cyprinus

\footnotetext{
* Correspondence: steven.vanbeurden@wur.nl

${ }^{1}$ Central Veterinary Institute of Wageningen UR, P.O. Box 65, 8200 AB

Lelystad, The Netherlands

Full list of author information is available at the end of the article
}

carpio spp.), the first being one of the most economically valuable aquaculture species worldwide [6,7].

The eel herpesvirus anguillid herpesvirus 1 (AngHV-1) causes a hemorrhagic disease in the European eel, Anguilla anguilla, with increased mortality rates [8]. Because of its omnipresence in wild Western European eel stocks, AngHV-1 is regarded as one of the possible factors responsible for the decline of the wild European eel stocks since the 1980s [9]. Although the fundamental characteristics of herpesviruses of especially humans and mammals have been studied intensively, there is still little knowledge on the herpesviruses of lower vertebrates and invertebrates.

Despite their diversity in genes, host range and genome size, the virion structure is conserved throughout the entire Herpesvirales order [1]. Herpesvirus virions invariably consist of a large (diameter $>100 \mathrm{~nm}$ ) icosahedral nucleocapsid $(T=16)$ containing the genome, surrounded by a host-derived envelope with a diameter of about $200 \mathrm{~nm}$, and an intervening proteinaceous layer called the tegument [10]. For a better understanding of the origins and replication cycle of members of the
C Biomed Central

(c) 2011 van Beurden et al; licensee BioMed Central Ltd. This is an Open Access article distributed under the terms of the Creative Commons Attribution License (http://creativecommons.org/licenses/by/2.0), which permits unrestricted use, distribution, and reproduction in any medium, provided the original work is properly cited. 
family Alloherpesviridae, the identification and characterization of the structural proteins of these alloherpesviruses is essential.

Mass spectrometry (MS) is a useful technique to identify proteins, particularly when sequence information about the protein composition is available [11]. The complete genome sequences of 5 alloherpesviruses have been determined to date and are publicly available: IcHV-1 [12], Ranid herpesvirus 1 (RaHV-1) and Ranid herpesvirus 2 (RaHV-2) [13], CyHV-3 [14] and AngHV1 [15]. In 1995, Davison and Davison identified a total of 16 principal structural proteins for IcHV-1 by MS [16]. To enable assigning the identified proteins to the different compartments of the herpesvirus virion (i.e. capsid, tegument and envelope), complete virions were fractionated into a capsid-tegument and an envelope fraction, and premature capsids were isolated directly from infected cell nuclei. Using this approach, 4 capsid proteins, 4 envelope proteins, 5 tegument proteins and 5 tegument-associated proteins were detected for IcHV-1.

Recently, a total of 40 structural proteins were identified by MS in mature CyHV-3 particles [17]. This number resembles the total number of structural proteins reported for members of the Herpersviridae family [18-25]. It is likely that the number of structural proteins detected earlier for IcHV-1 is an underrepresentation of the actual number, caused by the limited sensitivity of MS at the time. The CyHV-3 structural proteins were assigned to the different herpesvirus compartments on the basis of sequence homology and bioinformatics [17]. Since sequence homology between CyHV-3 and IcHV-1 is limited, the putative location in the virion of the majority of the identified proteins could not be assigned.

The current study aimed at identifying and characterizing the structural proteins of AngHV-1. The approach in fact entails a combination of the capsid retrieval and virion fractionation techniques previously used for IcHV-1 [16], and the high sensitivity liquid chromatography tandem mass spectrometry (LC-MS/MS) approach used for CyHV-3 [17]. The envelope proteins were further characterized using bioinformatics. The results of this study not only provide insight into the protein composition of the mature extracellular AngHV1 virions, but also give a first indication of the conservation of structural proteins within the Alloherpesviridae family.

\section{Materials and methods}

\section{Production and purification of AngHV-1 virions}

The Dutch AngHV-1 strain CVI500138 [26] was isolated and propagated in monolayers of eel kidney (EK-1) cells [27] in $150 \mathrm{~cm}^{2}$ cell culture flasks infected at a multiplicity of infection of 0.1 as described previously
[15]. Virions were purified from the culture medium using a previously described protocol with some modifications [28]. Three days post-infection, cell culture medium containing cell-released mature virions was collected and cleared from cell debris by centrifugation at $3500 \times g$ for $20 \mathrm{~min}$ at $4^{\circ} \mathrm{C}$ (Hermle Labortechnik Z400K, Wehingen, Germany). From here on virus was kept on ice. Virus was pelleted by ultracentrifugation at $22000 \mathrm{rpm}$ for $90 \mathrm{~min}$ at $4^{\circ} \mathrm{C}$, with slow acceleration and slow deceleration (Beckman Coulter Optima L70K Ultracentrifuge with rotor SW28, Brea, CA, USA). The pellet was resuspended in $1 \mathrm{ml}$ TNE buffer $(50 \mathrm{mM}$ Tris- $\mathrm{HCl}, 150 \mathrm{mM} \mathrm{NaCl}, 1 \mathrm{mM}$ EDTA, $\mathrm{pH}=7.5$ ) by pipetting and vortexing. The virus suspension was layered onto a 10 to $60 \%$ linear sucrose gradient in TNE buffer. Following ultracentrifugation (rotor SW41Ti, 22 $000 \mathrm{rpm}$ for $18 \mathrm{~h}$ at $4^{\circ} \mathrm{C}$ ), the virus band was collected. Subsequently, the virus was washed in 10 volumes of TNE buffer and concentrated by ultracentrifugation (rotor SW41Ti, $30000 \mathrm{rpm}$ for $3 \mathrm{~h}$ at $4^{\circ} \mathrm{C}$ ). The virus pellet was resuspended in $200 \mu \mathrm{L}$ TNE buffer and stored at $-80^{\circ} \mathrm{C}$ until further use.

\section{Fractionation of AngHV-1}

Lipid envelopes were released from the capsid-teguments by incubation with a nonionic detergent as described previously [16]. Briefly, an equal volume of solubilization buffer $(50 \mathrm{mM}$ Tris- $\mathrm{HCl}, 0.5 \mathrm{M} \mathrm{NaCl}, 20$ mM EDTA, 2\% (v/v) Nonidet P40) was added to the virus solution, incubated on ice for $15 \mathrm{~min}$, and microcentrifuged at $25000 \times g$ for $5 \mathrm{~min}$ at $4{ }^{\circ} \mathrm{C}$ (Eppendorf 5417R, Hamburg, Germany). Supernatant containing the envelopes was collected by pipetting. The capsid-tegument pellet was washed by vortexing in $100 \mu \mathrm{L}$ of icecold $0.5 \mathrm{x}$ solubilization buffer followed by microcentrifugation at $25000 \times g$ for $5 \mathrm{~min}$ at $4^{\circ} \mathrm{C}$. The supernatant was discarded by pipetting, $50 \mu \mathrm{L}$ of cold TNE-buffer was added, and the pellet was resuspended by probe sonication (MSE, London, UK) for $10 \mathrm{~s}$. The envelope fraction was clarified further by three subsequent microcentrifugation steps $\left(25000 \times g\right.$ for $5 \mathrm{~min}$ at $\left.4^{\circ} \mathrm{C}\right)$, each time collecting the supernatant by decantation. The capsid-tegument and envelope fractions were stored at $-80^{\circ}$ $\mathrm{C}$ until further use.

\section{Purification of AngHV-1 capsids}

AngHV-1 infected EK-1 cells were washed with PBS to remove complete virus particles. Cells from $4150 \mathrm{~cm}^{2}$ cell culture flasks were collected by scraping using a rubber policeman in $9 \mathrm{~mL}$ ice-cold TNE buffer. Cells were lysed by adding $1 \mathrm{~mL}$ of $10 \%(\mathrm{v} / \mathrm{v})$ Triton X-100 in TNE (final concentration $1 \%(\mathrm{v} / \mathrm{v})$ Triton $\mathrm{X}-100)$ and probe sonication on ice for three times $20 \mathrm{~s}$. Debris was pelleted by ultracentrifugation (rotor SW41Ti, 10000 
rpm for $10 \mathrm{~min}$ at $4^{\circ} \mathrm{C}$ ). Capsids were purified by sucrose cushion (40\% in TNE) ultracentrifugation (20 $000 \mathrm{rpm}$ for $1 \mathrm{~h}$ at $4^{\circ} \mathrm{C}$ ). The pellet was resuspended in $0.5 \mathrm{~mL}$ TNE and further purified by centrifugation on a linear 10-60\% sucrose gradient in TNE for $1 \mathrm{~h}$ at 20000 rpm. The two resulting bands, presumably containing capsids, were separately collected as an upper and a lower band, washed in TNE buffer and pelleted by ultracentrifugation (20 $000 \mathrm{rpm}$ for $1 \mathrm{~h}$ at $4^{\circ} \mathrm{C}$ ). The supernatant was discarded, the capsid pellets resuspended in $200 \mu \mathrm{L}$ TNE buffer and stored at $-80^{\circ} \mathrm{C}$ until further use.

\section{Electron microscopy}

Nickel grids (400-mesh) with a carbon-coated collodion film were placed upside down on a drop of complete virion suspension, virion fraction suspension or capsid suspension, and incubated for $10 \mathrm{~min}$. After incubation, grids were washed with distilled water and stained with $2 \%$ phosphotungstic acid ( $\mathrm{pH}=6.8)$. Grids were examined with a Philips CM10 transmission electron microscope (Amsterdam, The Netherlands).

\section{SDS-PAGE}

Proteins in purified virions, virion fractions and capsids were analyzed by sodium dodecyl sulfate polyacrylamide gel electrophoresis (SDS-PAGE). Virions in TNE buffer were mixed $1: 1$ with denaturizing sample buffer containing dithiothreitol (DTT) and heated for $5 \mathrm{~min}$ at $95^{\circ}$ C. Samples were loaded onto $12 \%$ NuPAGE Novex BisTris gels (Invitrogen by Life Technologies, Carlsbad, CA, USA) and ran for $2 \mathrm{~h}$ at $80 \mathrm{~V}$ in NuPAGE MOPS SDS-running buffer (Invitrogen). Gels were stained with Coomassie blue R-250 (Merck, Whitehouse Station, NJ, USA) or Silver (PlusOne Silver Staining Kit, GE Healthcare, Chalfont St. Giles, UK).

\section{LC-MS/MS approach}

The capsid proteins in the upper band were analyzed by SDS-PAGE and stained with Coomassie blue. The five visible protein bands were collected separately in gel slices. The gel segments were incubated in $10 \mathrm{mM}$ DTT in $50 \mathrm{mM}$ ammonium bicarbonate $(\mathrm{ABC})$ buffer at $60^{\circ} \mathrm{C}$ for $1 \mathrm{~h}$ to reduce disulfide bridges and subsequently in $100 \mathrm{mM}$ iodoacetamide (Sigma-Aldrich, St. Louis, MO, USA) in ABC buffer at room temperature for $1 \mathrm{~h}$ in the dark. After a final wash step with $A B C$ buffer, the gel material was dried. Trypsin digestion was performed as described previously by Ince et al. [29]. In short, in-gel protein digestion was performed using sequencing grade modified porcine trypsin (Promega, Madison, WI, USA) in $\mathrm{ABC}$ buffer $(10 \mathrm{ng} / \mu \mathrm{L})$. After incubation overnight, samples were bath sonicated, and after centrifugation the basic supernatants were collected. The remaining gel pieces were extracted with $10 \%$ triflouroacetic acid
(TFA), followed by $5 \%$ TFA, followed by $15 \%$ acetonitrile/1\% TFA. The latter extracts were combined with the supernatants of the original digests, vacuum-dried, and dissolved in $20 \mu \mathrm{L} 0.1 \%$ formic acid in water. The peptides resulting from this digestion were analyzed by LC-MS/MS as described previously [29].

\section{D gel/nanoLC-MS/MS approach}

Proteins from purified virions and from the three virion fractions (capsid, envelope and capsid-tegument) were separated by SDS-PAGE on 4-20\% acrylamide $7 \mathrm{~cm}$ gels (Invitrogen) and stained with Coomassie blue. Separated proteins in the gel were excised in 20 and 30 serial slices along the lane, for complete virions and virion fractions, respectively. Gel slices were submitted to in-gel digestion with sequencing grade modified trypsin as described previously [17]. Briefly, gels were washed successively with $\mathrm{ABC}$ buffer and $\mathrm{ABC}$ buffer/acetonitrile $(\mathrm{ACN}) 50 \%(\mathrm{v} / \mathrm{v})$. Proteins were reduced and alkylated using DTT and iodoacetamide followed by washing with $A B C$ and $A B C / A C N$. Resulting peptides were analyzed by $1 \mathrm{D}$ gel/nanoLC-MS/MS using a $40 \mathrm{~min} A C N$ gradient as described by Mastroleo et al. [30].

\section{D nanoLC-MS/MS approach}

Only proteins of purified complete virions were submitted to 2D nanoLC-MS/MS analysis. Proteins were extracted from complete virions using guanidine chloride (GC) as described previously [17]. In short, the virions were suspended in $6 \mathrm{M} \mathrm{GC}$ and sonicated for 5 min and shaken at $900 \mathrm{rpm}$ for $30 \mathrm{~min}$ at room temperature. After centrifugation the proteins were reduced with $10 \mathrm{mM} \mathrm{DTT}$ at $60^{\circ} \mathrm{C}$ for $30 \mathrm{~min}$ and alkylated with $25 \mathrm{mM}$ iodoacetamide at $25^{\circ} \mathrm{C}$ for $30 \mathrm{~min}$ in the dark. Proteins were recovered by acetone precipitation and dissolved in $50 \mathrm{mM}$ Tris $/ \mathrm{HCl}(\mathrm{pH}=8), 2 \mathrm{M}$ urea. The proteins were digested overnight at $37^{\circ} \mathrm{C}$ with trypsin (enzyme : substrate ratio $=1: 50$ ). Tryptic peptides were cleaned using spin tips (Thermo Fisher Scientific, Waltham, MA, USA) according to the manufacturer's instructions. Proteins were analyzed by $2 \mathrm{D}$ (strong cation exchange, reverse-phase) chromatography and online MS/MS, as described by Mastroleo et al. [30] except that only 3 salt plugs of 25, 100 and $800 \mathrm{mM}$ $\mathrm{NH}_{4} \mathrm{Cl}$ were analyzed in addition to the SCX flow through.

\section{MS/MS analyses}

Peptides were analyzed using an HCT ultra ion Trap (Bruker, Billerica, MA, USA). Peptide fragment mass spectra were acquired in data-dependent AutoMS(2) mode for 4 most abundant precursor ions in all MS scan. After acquisition of 2 spectra, precursors were actively excluded within a 2 min window, and all singly 
charged ions were excluded. Data were processed using Mascot Distiller with default parameters. An in-house Mascot 2.2 server (Matrix Science, London, UK) was used for dataset searching against the NCBI Alloherpesviridae database. The default search parameters used were the following: Enzyme = Trypsin; Maximum missed cleavages $=2$; Fixed modifications $=$ Carbamidomethyl (C); Variable modifications = Oxidation (M); Peptide tolerance \pm 1.5 Dalton (Da); MS/MS tolerance \pm $0.5 \mathrm{Da}$; Peptide charge $=2+$ and $3+$; Instrument $=$ ESITRAP. Only sequences identified with a Mascot Score greater than 30 were considered, which indicates identity or extensive homology $(p$-value $<0.05)$. Single peptide identification was systematically evaluated manually. The exponentially modified protein abundance index (emPAI) [31] was calculated to estimate protein relative abundance for the complete virion extracts. The protein abundance index (PAI) is defined as the number of observed peptides divided by the number of observable peptides per protein. The exponentially modified PAI $\left(10^{\mathrm{PAI}}-1\right)$ is proportional to protein content in a protein mixture in LC-MS/MS experiments.

\section{Bioinformatics}

The amino acid sequences of all identified AngHV-1 structural proteins were analyzed using bioinformatic tools from the CBS website [32] to identify potential transmembrane domains (TMHMM) [33], signal peptides (SignalP) [34], and glycosylation sites (NetNGlyc [35] and NetOGlyc [36]).

\section{Results and Discussion}

\section{Electron microscopy}

Purified virus, fractionated virus, and purified capsids were checked for quality by transmission electron microscopy (EM, pictures not shown). The preparation of purified virus contained complete virions with intact or disrupted envelope, capsids and envelopes. The upper band of sucrose gradient purified capsids primarily contained capsids with an electron-lucent inner appearance, while the lower band showed capsids with an electrondense core. No cell debris was seen in the capsid fractions. In the capsid-tegument fraction, only capsids and no envelopes were visible. The envelopes in the envelope fraction were largely unrecognizable and present as clusters of membrane remnants. Only very few capsids contaminated the envelope fraction. Overall, the virus and capsid purification as well as the virus fractionation could be considered successful, at least as evaluated by EM.

Davison and Davison [16] already mentioned for IcHV-1 that the resulting upper and lower bands after capsid purification parallel the density separation of mammalian herpesvirus capsids into $\mathrm{A}, \mathrm{B}$ and $\mathrm{C}$ forms (in order of increasing density) as initially described by Gibson and Roizman [37]. The lower band consists of capsids comparable to the mature DNA-containing C form capsids, while the upper band comprises both the immature DNA-lacking B form capsids (containing additional core proteins) and the erroneous DNA-lacking $\mathrm{A}$ form capsids. For the sake of clarity in this paper we will follow the nomenclature as initially proposed for the IcHV-1 capsids: U capsids for the capsids found in the upper ( $U$ ) band and L capsids for the capsids found in the lower (L) band [16]. The L capsid fraction contained significantly more DNA-containing capsids than the $U$ capsid fraction (data not shown). This was in agreement with earlier observations on DNA content of premature mammalian herpesvirus capsids [38,39], and with the current view of herpesvirus capsids being first assembled around a scaffold with the DNA being inserted later [40].

\section{SDS-PAGE}

Proteins in purified virions, capsids and virion fractions were analyzed by SDS-PAGE to check purity and analyze the protein content of the different virion compartments. Thirty-five bands were visible for the complete virions using silver staining (Figure 1). Purified L capsids showed 4 clear bands, the $U$ capsids showed an additional fifth protein band of low molecular weight not present in complete virus particles (Figure 1a). The

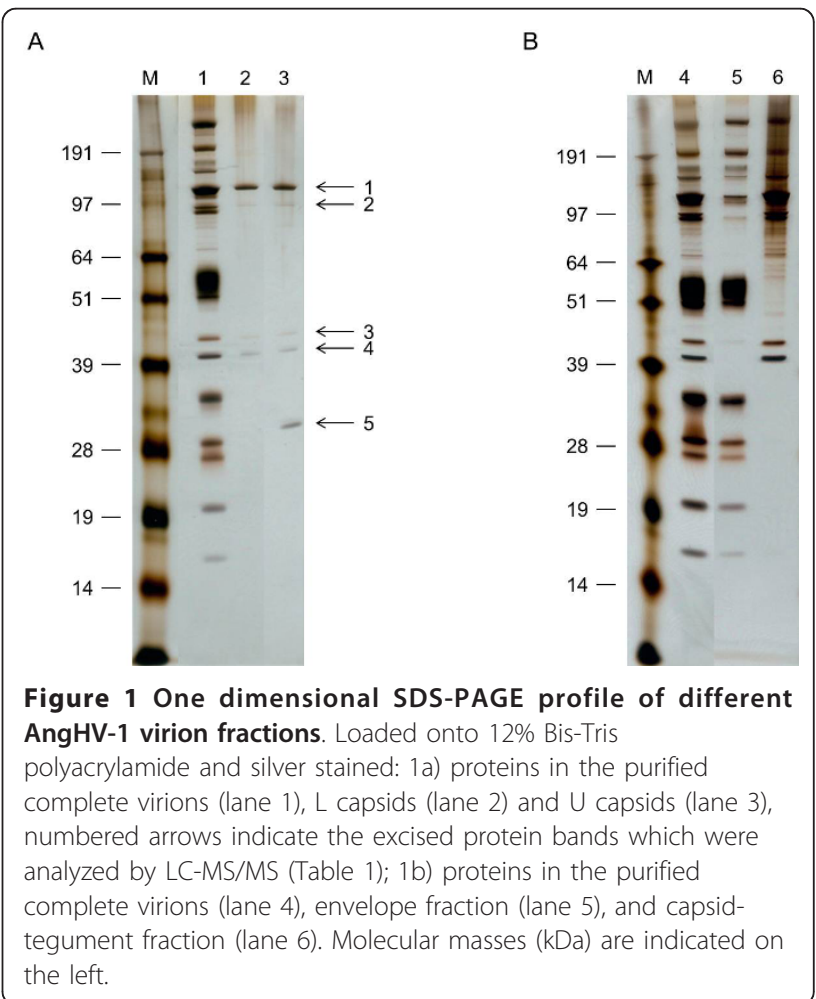


envelope fraction resulted in 20 proteins (Figure $1 \mathrm{~b}$ ). The capsid-tegument fraction resulted in a smear in the high molecular weight region and at least 27 individual proteins could be differentiated. All four L capsid proteins were also present in the capsid-tegument fraction. Several proteins were predominant in either the envelope-tegument or the capsid-tegument fraction, but at least 8 proteins were clearly present in both fractions, presumably representing tegument-associated proteins.

\section{AngHV-1 capsid proteins}

The five $U$ capsid proteins were excised from a Coomassie blue stained gel and identified by LC-MS/MS. The proteins were identified as the major capsid protein (ORF104), the proteins encoded by ORF48 and ORF42, and the capsid triplex protein 2 (ORF36) (Table 1). The fifth protein, which did not seem to be present in the $\mathrm{L}$ capsids, appeared to be the capsid protease-and-scaffolding protein (ORF57). Indeed, in mammalian herpesviruses, this protein serves as a scaffold around which the capsid is built, and is proteolytically cleaved and extruded at the moment of DNA incorporation in the capsid [40].

Based on size and relative abundance compared to the capsid triplex protein 2 and the major capsid protein, AngHV-1 ORF42 is the best candidate to encode the capsid triplex protein 1 (expected ratio $1: 2: 3$ $[37,41])$. ORF42 shows no convincing sequence homology with its putative functional homologue in IcHV-1 ORF53 [16]. It shows sequence homology, however, with ORF66 of the more closely related CyHV-3, encoding an abundant structural protein [17]. This low sequence conservation of the capsid triplex protein 1 is comparable with the sequence conservation among the capsid proteins of members of the Herpesviridae family [16]. Another highly abundant and large capsid protein is encoded by AngHV-1 ORF48, for which sequence homology was absent, however.

To obtain complementary data another gel loaded with $U$ capsid proteins separated by SDS-PAGE was divided into 30 serial slices which were analyzed with 1D gel/nanoLC-MS/MS. This analysis resulted in the identification of another 6 low abundant proteins, of which 4 were contaminating other high abundant structural proteins, and 2 were additional putative capsid proteins. For the protein encoded by the spliced ORF100, 9 peptides were found in the $U$ capsid fraction. Its high conservation among other alloherpesviruses hints to a possibly important but yet unknown function. The protein encoded by AngHV-1 ORF126 was little abundant (only 2 peptides in the $U$ capsid fraction) and is not conserved in other herpesviruses. The overall high rate of capsid protein conservation (5 out of 7 ) was comparable with that of members of the Herpesviridae family and resembles the functional conservation of capsid structure in the Herpesvirales order.

\section{AngHV-1 envelope proteins}

Removal of virus envelopes by treatment with a nonionic detergent has allowed proteins to be assigned as components of the envelope versus capsid-tegument [16]. Proteins were principally defined as envelope proteins when present in the envelope fraction in higher concentrations (based on their emPAI) than in the capsid-tegument fraction, and when having certain characteristics of membrane proteins. A total of 30 proteins were identified by $1 \mathrm{D}$ gel/nanoLC-MS/MS in this sample and based on the former criteria 10 were annotated as putative envelope proteins (Table 2). Sixteen of the 20 non-envelope proteins were putative tegument proteins (Table 3), 4 were putative capsid proteins and little abundant. Eight of the envelope proteins comprised both a transmembrane domain and a signal peptide or anchor. The proteins encoded by ORF8 and ORF108 lacked a signal peptide, but were exclusively detected in the envelope fraction and not in the capsid-tegument fraction. The presumed multiple transmembrane protein encoded by AngHV-1 ORF49 was only detected in very low abundance in complete virion preparations and not in one of the virion fractions. The CyHV-3 homologue of this protein (ORF83) was not detected in CyHV-3 virions [17], possibly due to its low abundance. A signal peptide was predicted for only one other structural protein of AngHV-1 (encoded by ORF103), but not a transmembrane domain. Moreover, this protein was exclusively found in the capsid-tegument fraction, indicating that it is a putative tegument protein and not an envelope protein.

The two ORF encoding the most abundant envelope proteins demonstrated interesting sequence homologies. The most abundant AngHV-1 envelope protein is encoded by ORF51, which shows low sequence homology with CyHV-3 ORF81 (E-value $\left.=10^{-4}\right)$ in a directed search against members of the Alloherpesviridae family. CyHV-3 ORF81 encodes an abundant multiple transmembrane protein, thought to be the immunodominant envelope protein of CyHV-3 [42]. CyHV-3 ORF81 is the positional homologue of IcHV-1 ORF59, the latter being the major envelope protein [16]. While the homologue of this protein also seems to be a major envelope protein in AngHV-1, only a few peptides of this protein were found in CyHV-3 virions [17].

The second most abundant AngHV-1 envelope protein, encoded by ORF95, was previously shown to be related to the haemagglutinin-esterase protein of infectious salmon anaemia virus (ISAV) $\left(\right.$ E-value $\left.=10^{-16}\right)$ [15]. In the piscine orthomyxovirus ISAV this viral 
Table 1 Capsid proteins of AngHV-1 as identified by 1D gel/nanoLC-MS/MS in purified U capsids

\begin{tabular}{|c|c|c|c|c|c|c|c|c|c|c|}
\hline $\mathrm{ORF}^{\mathrm{a}}$ & NCBI ID & Band $^{b}$ & Description $^{c}$ & Predicted molecular mass (kDa) & Number of peptides ${ }^{d}$ & Mascot score & CyHV-3 ${ }^{e}$ & IcHV-1 & RaHV-1 & RaHV-2 \\
\hline 36 & 282174073 & 4 & Capsid triplex protein 2 & 40.2 & 91 & 3724 & ORF72 & ORF27 & ORF95 & ORF131 \\
\hline 42 & 282174079 & 3 & Capsid triplex protein 1 & 42.9 & 75 & 3288 & ORF66 & & & \\
\hline 48 & 282174085 & 2 & & 102.6 & 52 & 2935 & & & & \\
\hline 57 & 282174094 & 5 & Capsid protease-and-scaffolding protein & 78.0 & 114 & 5037 & ORF78 & ORF28 & ORF63 & ORF88 \\
\hline 100 & 282174137 & - & & 61.1 & 9 & 381 & ORF90 & ORF37 & ORF52 & ORF78 \\
\hline 104 & 282174141 & 1 & Major capsid protein & 139.9 & 537 & 26277 & ORF92 & ORF39 & ORF54 & ORF80 \\
\hline 126 & 282174163 & & & 22.4 & 2 & 89 & & & & \\
\hline
\end{tabular}

athe ORF are ordered by number, ${ }^{b}$ band number refers to the capsid protein bands shown in Figure 1a, cproperties newly suggested in this paper are presented in italics, ${ }^{d}$ number of peptides and Mascot score in the $\mathrm{U}$ capsid fraction, and ${ }^{\mathrm{e}}$ homologous ORF in CyHV-3, ICHV-1, RaHV-1 and RaHV-2 are given, in case of marginal sequence identity (E-value $>10^{-5}$ in a BLAST search limited to members of the Alloherpesviridae family) presented in italics. 
Table 2 Envelope proteins of AngHV-1 as identified by 1D gel/nanoLC-MS/MS in the envelope fraction

\begin{tabular}{|c|c|c|c|c|c|c|c|c|c|c|c|}
\hline $\mathrm{ORF}^{\mathrm{a}}$ & NCBI ID & Description $^{b}$ & $\begin{array}{l}\text { Predicted molecular } \\
\text { mass }(\mathrm{kDa})\end{array}$ & $\begin{array}{l}\text { Number of } \\
\text { peptides }^{c}\end{array}$ & $\begin{array}{l}\text { Mascot } \\
\text { score }\end{array}$ & CyHV-3 & $\begin{array}{l}\text { Membrane } \\
\text { protein type }\end{array}$ & $\begin{array}{l}\text { Trans-membrane } \\
{\text { domain }(\mathbf{s})^{\mathrm{e}}}\end{array}$ & $\begin{array}{l}\text { Signal anchor or } \\
\text { peptide }\end{array}$ & $\begin{array}{l}\mathrm{N}- \\
\text { glyco }^{\mathrm{f}}\end{array}$ & $\begin{array}{l}\text { O- } \\
\text { glyco }^{g}\end{array}$ \\
\hline 8 & 282174045 & & 21.2 & 46 & 2390 & & Type 1 & oli & - & 4 & - \\
\hline $49^{h}$ & 282174086 & & 26.4 & - & - & ORF83 & Type 3 & $i 4 i$ & Signal peptide & - & - \\
\hline 51 & 282174088 & Major envelope protein & 26.5 & 137 & 5970 & ORF81 & Type 3 & $i 4 i$ & Signal anchor & 1 & 1 \\
\hline 66 & 282174103 & & 42.7 & 1 & 46 & & Type 1 & o1i & Signal peptide & 4 & 2 \\
\hline 67 & 282174104 & $\begin{array}{l}\text { WBV spike protein/Major } \\
\text { glycoprotein }\end{array}$ & 152.9 & 54 & 2251 & ORF99 & Type 1 & o1i & Signal peptide & 13 & 8 \\
\hline 71 & 282174108 & & 11.4 & 29 & 1638 & & Type 1 & o1i & Signal anchor & - & 2 \\
\hline 78 & 282174115 & & 16.9 & 8 & 609 & & Type 3 & $\mathrm{i} 2 \mathrm{i}$ & Signal peptide & - & - \\
\hline 95 & 282174132 & ISAV HA & 41.6 & 190 & 11573 & & Type 1 & oli & Signal peptide & 5 & 1 \\
\hline 108 & 282174145 & ORF80 family & 108.2 & 4 & 183 & & Type 1 & o1i & - & 3 & 56 \\
\hline 115 & 282174152 & & 12.1 & 6 & 406 & & Type 1 & o1i & Signal anchor & 2 & - \\
\hline 125 & 282174162 & ORF109 family & 120.5 & 2 & 189 & & Type 1 & oli & Signal peptide & 16 & 16 \\
\hline
\end{tabular}

the ORF are ordered by number, ${ }^{b}$ properties newly suggested in this paper are presented in italics, ${ }^{c}$ number of peptides and Mascot score in the envelope fraction, ${ }^{d}$ homologous ORF in CyHV-3 are given, in case of marginal sequence identity (E-value $>10^{-5}$ in a BLAST search limited to members of the Alloherpesviridae family) presented in italics, ${ }^{e}$ transmembrane domain(s) and orientation: $\mathrm{o}=\mathrm{outside}^{\mathrm{i}} \mathrm{i}=$ inside, number refers to number of transmembrane domains, ${ }^{\mathrm{f}}$ predicted $\mathrm{N}$-glycosylation site(s), ${ }^{\mathrm{g}}$ predicted O-glycosylation site(s), and ${ }^{\mathrm{h}} \mathrm{AngHV}-1$ ORF49 was only detected in very low abundance in complete virion preparations, and not in the envelope fraction. 
Table 3 Tegument proteins of AngHV-1 as identified by 1D gel/nanoLC-MS/MS in the capsid-tegument and envelope fraction

\begin{tabular}{|c|c|c|c|c|c|c|c|c|c|}
\hline $\mathrm{ORF}^{\mathrm{a}}$ & NCBI ID & Description $^{\text {b }}$ & $\begin{array}{l}\text { Predicted molecular } \\
\text { mass }(\mathrm{kDa})\end{array}$ & $\begin{array}{l}\text { Number of peptides } \\
\text { (tegument) }\end{array}$ & $\begin{array}{l}\text { Mascot } \\
\text { score }\end{array}$ & $\begin{array}{l}\text { Number of peptides } \\
\text { (envelope) }^{\mathrm{d}}\end{array}$ & $\begin{array}{l}\text { Mascot } \\
\text { score }\end{array}$ & CyHV-3 & $\begin{array}{l}\text { Putative } \\
\text { classification }^{\mathrm{f}}\end{array}$ \\
\hline 14 & 282174051 & ORF3 family & 32.3 & 2 & 63 & - & - & & Tegument protein \\
\hline 16 & 282174053 & ORF13 family & 33.8 & 4 & 237 & 12 & 905 & & $\begin{array}{l}\text { Tegument-associated } \\
\text { protein }\end{array}$ \\
\hline 17 & 282174054 & ORF13 family & 25.8 & 13 & 851 & 29 & 1496 & & $\begin{array}{l}\text { Tegument-associated } \\
\text { protein }\end{array}$ \\
\hline 18 & 282174055 & & 233.6 & 4 & 177 & - & - & ORF42 & Tegument protein \\
\hline 19 & 282174056 & & 93.7 & 40 & 1717 & 7 & 372 & & Tegument protein \\
\hline 20 & 282174057 & & 63.1 & 6 & 304 & - & - & ORF45 & Tegument protein \\
\hline 24 & 282174061 & ORF13 family & 29.3 & 12 & 842 & 39 & 2690 & & $\begin{array}{l}\text { Tegument-associated } \\
\text { protein }\end{array}$ \\
\hline 26 & 282174063 & & 18.4 & 1 & 38 & 2 & 74 & & $\begin{array}{l}\text { Tegument-associated } \\
\text { protein }\end{array}$ \\
\hline 30 & 282174067 & & 118.4 & 94 & 5311 & 70 & 3350 & ORF97 & $\begin{array}{l}\text { Tegument-associated } \\
\text { protein }\end{array}$ \\
\hline 32 & 282174069 & & 20.0 & 2 & 101 & 5 & 192 & & $\begin{array}{l}\text { Tegument-associated } \\
\text { protein }\end{array}$ \\
\hline 34 & 282174071 & & 195.0 & 176 & 9205 & 167 & 8820 & ORF51 & $\begin{array}{l}\text { Tegument-associated } \\
\text { protein }\end{array}$ \\
\hline 35 & 282174072 & & 33.4 & 12 & 576 & 46 & 2113 & ORF57 & $\begin{array}{l}\text { Tegument-associated } \\
\text { protein }\end{array}$ \\
\hline 38 & 282174075 & & 44.1 & 10 & 455 & - & - & ORF70 & Tegument protein \\
\hline 39 & 282174076 & & 62.7 & 1 & 65 & - & - & ORF69 & Tegument protein \\
\hline 40 & 282174077 & & 162.7 & 101 & 4570 & 21 & 921 & & Tegument protein \\
\hline 43 & 282174080 & & 18.0 & 18 & 1444 & 35 & 2491 & & $\begin{array}{l}\text { Tegument-associated } \\
\text { protein }\end{array}$ \\
\hline 81 & 282174118 & & 51.5 & 10 & 561 & 48 & 2673 & ORF60 & $\begin{array}{l}\text { Tegument-associated } \\
\text { protein }\end{array}$ \\
\hline 83 & 282174120 & $\begin{array}{l}\text { Cysteine protease domain/Large } \\
\text { tegument protein }\end{array}$ & 376.8 & 538 & 28887 & 298 & 16343 & ORF62 & $\begin{array}{l}\text { Tegument-associated } \\
\text { protein }\end{array}$ \\
\hline 103 & 282174140 & & 25.0 & 5 & 273 & - & - & ORF91 & Tegument protein \\
\hline 114 & 282174151 & & 20.7 & 19 & 913 & 61 & 3202 & & $\begin{array}{l}\text { Tegument-associated } \\
\text { protein }\end{array}$ \\
\hline 128 & 282174165 & & 17.9 & 11 & 394 & 6 & 225 & & $\begin{array}{l}\text { Tegument-associated } \\
\text { protein }\end{array}$ \\
\hline 129 & 282174166 & & 42.2 & 16 & 935 & 9 & 579 & & $\begin{array}{l}\text { Tegument-associated } \\
\text { protein }\end{array}$ \\
\hline
\end{tabular}

the ORF are ordered by number, ${ }^{b}$ properties newly suggested in this paper are presented in italics, ${ }^{\text {c }}$ number of peptides and Mascot score in the capsid-tegument fraction, ${ }^{\mathrm{d}}$ number of peptides and Mascot score in the envelope fraction, e homologous ORF in CyHV-3 are given, in case of marginal sequence identity (E-value $>10^{-5}$ in a BLAST search limited to members of the Alloherpesviridae family) presented in italics, and fputative classification into a tegument or tegument-associated protein. 
surface glycoprotein is responsible for viral attachment and release [43]. Herpesviruses are known to be capable of gene capture from cells or other viruses. Likewise AngHV-1 ORF95 might originate from ISAV or, for example, from a yet uncharacterized eel orthomyxovirus (Olga Haenen, personal communication).

AngHV-1 ORF67, encoding a large envelope protein, was previously shown to exhibit sequence homology with the White bream virus (WBV) spike protein (Evalue $=10^{-24}$ ) [15], a protein probably mediating receptor binding and fusion between viral and cellular membranes [44]. A search for the yet unidentified AngHV-1 homologue of the presumed major glycoprotein present in other alloherpesviruses (IcHV-1 ORF46 [12], CyHV-3 ORF99 [14], RaHV-1 ORF46 [13] and RaHV-2 ORF72 [13]) resulted in low sequence homology of AngHV-1 ORF67 with RaHV-1 ORF46 (E-value $=10^{-3}$ ) in particular. The latter finding raises questions about the origin of AngHV-1 ORF67. One option might be that the current AngHV-1 ORF67 is the result of gene capture from WBV and subsequent genetic reassortment with the original major glycoprotein.

Human herpesviruses carry between 12 and 20 viral membrane proteins in their envelope [45]. For the alloherpesviruses CyHV-3 and AngHV-1, a total of 13 [17] and 11 (this paper) viral envelope proteins were predicted, respectively. Despite their large genomes, these alloherpesviruses seem to encode a relatively low number of membrane proteins. Many envelope proteins are specific to each herpesvirus type. However, among the members of the Herpesviridae family five glycoproteins are broadly conserved, namely $\mathrm{gB}, \mathrm{gH}, \mathrm{gL}, \mathrm{gM}$ and $\mathrm{gN}$ [45]. Glycoprotein $\mathrm{gB}$ and a complex formed by $\mathrm{gH}$ and $\mathrm{gL}$ are involved in the fusion of the viral envelope and plasma membrane. Glycoproteins $\mathrm{gM}$ and $\mathrm{gN}$ form another complex. The fact that only two envelope proteins seem to be conserved among the members of the Alloherpesviridae family, is yet another indication that the evolutionary distance among fish and amphibian herpesviruses is greater than among mammalian, bird and reptile herpesviruses.

\section{AngHV-1 tegument proteins}

Comparison of the proteins found in the capsid-tegument fraction with the proteins identified in purified capsids allowed the identification of the tegument proteins. Tegument proteins were defined as proteins found in the capsid-tegument fraction, but not (or only in trace amounts) in the purified capsid fraction, and not meeting the criteria as defined for envelope proteins. A total of 32 proteins were identified by 1D gel/nanoLCMS/MS in the capsid-tegument sample, 22 of which were considered to be tegument proteins (Table 3). Six tegument proteins were exclusively found in the capsid- tegument fraction and for two other capsid-tegument proteins (ORF19 \& ORF40) relatively high amounts were detected in the capsid-tegument fraction and relatively low amounts in the envelope fraction. Hence these proteins were called tegument proteins. The majority (14) of the proteins in the capsid-tegument fraction was, however, also found in the envelope fraction, indicating that these proteins are rather loosely bound to the tegument. These proteins were therefore classified as tegument-associated proteins. This distinction between true tegument and tegument-associated proteins is arbitrary and presumably depends on the fractionation conditions used. A more precise differentiation would be based on the interaction of the tegument proteins with either the capsid ("inner tegument") or the cytoplasmic domains of viral envelope proteins ("outer tegument") $[40,46]$.

Nine sequence similarity based gene families have been identified within the AngHV-1 genome [15]. Most of these ORF encode proteins with unknown functions. Three of the four proteins of the ORF13 gene family were identified as tegument-associated proteins, indicating that this gene family encodes proteins with a tegument-related function.

Among the 22 tegument(-associated) proteins found, 10 showed sequence homology with CyHV-3 ORF, which therefore can now be classified as presumed tegument proteins. The largest AngHV-1 tegument-associated protein, ORF83, contains a cysteine protease domain in the $\mathrm{N}$-terminal region homologous to the Ovarian Tumor gene in Drosophila [47]. This domain is also found in CyHV-3 ORF62 and IcHV-1 ORF65. Based on its size and conservation, this ORF has been suggested by Michel et al. [17] to encode the homologue of the large tegument protein UL36, which is conserved among the members of the Herpesviridae family $[46,48]$. UL36 is an essential and abundant structural polypeptide with multiple functions. It binds to the capsid on the one hand, and to several major tegument components on the other hand, suggesting that UL36 plays an important role in the structural organization of the tegument. A putative function could not be determined for any of the other AngHV-1 tegument(-associated) proteins.

Except for the large tegument protein, no significant sequence homology of tegument proteins was found with any of the other alloherpesviruses. This suggests that conservation of the tegument proteins is high between closely related alloherpesviruses, but hardly present throughout the whole family. This level of conservation reflects the greater divergence of the Alloherpesviridae family compared to the Herpesviridae family, among which almost a dozen tegument proteins are conserved $[46,49,50]$. More sequence data from other 
alloherpesviruses and functional characterization of yet identified tegument proteins is necessary to determine the exact level of tegument protein conservation [45].

\section{AngHV-1 virion composition}

In order to unravel the relative abundance of the structural proteins of AngHV-1, proteins from purified virions separated by SDS-PAGE were excised from the gel in 20 serial slices. After in-gel digestion, the resulting peptides were analyzed by $1 \mathrm{D}$ gel/nanoLC-MS/MS. An in-solution trypsin digest MS approach, termed 2D nanoLC-MS/MS, was used as a complement to this gel based LC-MS/MS approach to enhance the recovery of peptides derived from proteins that are prone to aggregation, contain hydrophobic peptides, or are present at low abundance. The 1D gel and 2D nanoLC-MS/MS analyses of complete virions resulted in the identification of 33 and 27 viral proteins respectively, with an overlap of 26 proteins (Table 4). All but one of these proteins had already been identified in the virion fractions. AngHV-1 ORF49, presumably encoding a type 3 membrane protein, was detected in very low abundance in both complete virion analyses.

For the 1D gel and 2D nanoLC-MS/MS analyses of complete virions the emPAI was calculated to estimate protein relative abundance (Table 4). The emPAI from both analyses is generally comparable. A schematic representation of the AngHV-1 virion was made based on predicted protein mass, localization of the structural proteins of AngHV-1 as determined by analyses of the respective fractions, and the relative abundance in complete virions as determined for the protein extract analyzed by $1 \mathrm{D}$ gel/nanoLC-MS/MS (Figure 2).

\section{Host proteins associated with AngHV-1 virions}

Several cellular host proteins end up in mature herpesvirus virions, either intentionally or accidentally in the process of virus assembly and release from the cell. We also performed searches for non-viral host-originating proteins for all LC-MS/MS datasets acquired in this study. The proteins were identified by searching the peptides against a bony vertebrate database, since there are only very few genomic Anguilla spp. sequences available. In the $1 \mathrm{D}$ gel and $2 \mathrm{D}$ nanoLC-MS/MS analyses of complete virions, 30 and 15 host proteins were detected, respectively, with an overlap of 3 proteins (Additional file 1). A total of 28 unique host proteins associated with AngHV-1 virions were found, compensating for the several hits against protein homologues in different (fish) species. This number is somewhat higher than the number of host proteins found to be associated with CyHV-3 [17]. It resembles numbers found for several mammalian herpesviruses, either cushion $[23,25]$ or gradient purified [24], however.
The host proteins found to be associated with AngHV-1 virions include cytoskeleton proteins ( $\alpha$-actin, $\beta$-actin, actin-depolymerization factor, filamin, keratin, profilin, septin, etc.), proteins involved in transport (fatty acid binding proteins, lipocalin, myelin), an adrenoreceptor-like protein, proteins involved in glycolysis (aldolase and glyceraldehyde-3-phosphate dehydrogenase) and protein glycosylation, regulatory proteins (ubiquitin and a WD repeat containing protein), a protein involved in translation control (Sp5 transcription factor), proteins involved in the immunological response (pentraxin) and stress-response (heat shock proteins 70 \& 90 ), and several proteins with yet unknown functions.

Several of the classifiable virion associated host proteins have also been described in CyHV-3 and mammalian herpesviruses [16-20,22-25]. The composition of the set of incorporated host proteins might, however, be influenced by the type of cell culture used for virus propagation. All virion associated host proteins were found in low concentrations of only 1 to a maximum of 18 peptides per protein (Additional file 1), suggesting that these proteins are only minor components of the virion. Although many of the identified host proteins have previously been associated with herpesvirus virions, it is possible that some of these proteins represent minor cellular contaminants of the virion preparations.

\section{Evaluation of the approach}

In this study, three approaches were followed for the detection of the structural proteins of AngHV-1. The first and most straight-forward method was the in-solution trypsin digest MS approach termed 2D nanoLCMS/MS. A total of 27 unique structural proteins were identified. The second approach was the extraction and separation of AngHV-1 virion proteins by SDS-PAGE, followed by excision of 20 contiguous sections of the gel along the migration path, in-gel trypsin digestion and subsequent nanoLC-MS/MS analysis. This approach resulted in the identification of another 7 unique AngHV-1 structural proteins. The third approach, which intended to assign the identified proteins to the different AngHV-1 virion compartments, resulted in the identification of another 6 structural proteins. The proteins detected by only one of the approaches were generally little abundant.

A total of 40 structural proteins of AngHV-1 were identified (Tables 1, 2, 3 and 4). This number is not likely to represent the actual total number of AngHV-1 structural proteins, but will nevertheless represent the majority. For the related CyHV-3 virion, a similar number of structural proteins was recently identified, but Michel et al. used several additional protein extraction methods before separating the virions by SDS-PAGE [17]. Based on their results we decided to use the two 


\begin{tabular}{|c|c|c|c|c|c|c|c|c|c|c|}
\hline \multirow[t]{2}{*}{$\mathrm{ORF}^{\mathrm{a}}$} & \multirow[t]{2}{*}{ NCBI ID } & \multirow[t]{2}{*}{ Location $^{\mathbf{b}}$} & \multirow[t]{2}{*}{ Description $^{c}$} & \multirow{2}{*}{$\begin{array}{l}\text { Predicted molecular } \\
\text { mass }(\mathrm{kDa})\end{array}$} & \multicolumn{2}{|c|}{ 1D gel/nanoLC-MS/MS ${ }^{d}$} & \multicolumn{3}{|c|}{ 2D nanoLC-MS/MS } & \multirow[b]{2}{*}{ EmPA } \\
\hline & & & & & $\begin{array}{l}\text { Number of } \\
\text { peptides }\end{array}$ & $\begin{array}{l}\text { Mascot } \\
\text { score }\end{array}$ & EmPAI & $\begin{array}{l}\text { Number of } \\
\text { peptides }\end{array}$ & $\begin{array}{l}\text { Mascot } \\
\text { score }\end{array}$ & \\
\hline 8 & 282174045 & Envelope & Membrane protein type 1 & 21.2 & 29 & 1138 & 1.3 & 37 & 1339 & 2.59 \\
\hline 14 & 282174051 & Tegument & ORF3 family & 32.3 & - & - & - & - & - & - \\
\hline 16 & 282174053 & $\begin{array}{l}\text { Tegument- } \\
\text { associated }\end{array}$ & ORF13 family & 33.8 & 12 & 349 & 0.88 & 11 & 465 & 0.66 \\
\hline 17 & 282174054 & $\begin{array}{l}\text { Tegument- } \\
\text { associated }\end{array}$ & ORF13 family & 25.8 & 21 & 1010 & 0.51 & 10 & 459 & 0.70 \\
\hline 18 & 282174055 & Tegument & & 233.6 & - & - & - & - & - & - \\
\hline 19 & 282174056 & Tegument & & 93.7 & 5 & 179 & 0.17 & 13 & 713 & 0.30 \\
\hline 20 & 282174057 & Tegument & & 63.1 & 3 & 123 & 0.19 & - & - & - \\
\hline 24 & 282174061 & $\begin{array}{l}\text { Tegument- } \\
\text { associated }\end{array}$ & ORF13 family & 29.3 & 11 & 493 & 1.07 & 11 & 471 & 0.59 \\
\hline 26 & 282174063 & $\begin{array}{l}\text { Tegument- } \\
\text { associated }\end{array}$ & & 18.4 & - & - & - & - & - & - \\
\hline 30 & 282174067 & $\begin{array}{l}\text { Tegument- } \\
\text { associated }\end{array}$ & & 118.4 & 23 & 801 & 0.54 & 16 & 450 & 0.34 \\
\hline 32 & 282174069 & $\begin{array}{l}\text { Tegument- } \\
\text { associated }\end{array}$ & & 20.0 & 5 & 239 & 1.41 & - & - & - \\
\hline 34 & 282174071 & $\begin{array}{l}\text { Tegument- } \\
\text { associated }\end{array}$ & & 195.0 & 71 & 2641 & 1.32 & 58 & 2200 & 0.71 \\
\hline 35 & 282174072 & $\begin{array}{l}\text { Tegument- } \\
\text { associated }\end{array}$ & & 33.4 & 19 & 797 & 1.35 & 18 & 632 & 0.67 \\
\hline 36 & 282174073 & Capsid & Capsid triplex protein 2 & 40.2 & 29 & 1016 & 3.99 & 22 & 856 & 1.80 \\
\hline 38 & 282174075 & Tegument & & 44.1 & 4 & 142 & 0.39 & - & - & - \\
\hline 39 & 282174076 & Tegument & & 62.7 & 2 & 57 & 0.12 & - & - & - \\
\hline 40 & 282174077 & Tegument & & 162.7 & 22 & 783 & 0.56 & 13 & 446 & 0.29 \\
\hline 42 & 282174079 & Capsid & Capsid triplex protein 1 & 42.9 & 20 & 979 & 1.73 & 17 & 558 & 1.42 \\
\hline 43 & 282174080 & $\begin{array}{l}\text { Tegument- } \\
\text { associated }\end{array}$ & & 18.0 & 4 & 121 & 0.48 & 8 & 291 & 1.12 \\
\hline 48 & 282174085 & Capsid & & 102.6 & 32 & 1112 & 1.18 & 26 & 876 & 0.97 \\
\hline 49 & 282174086 & Envelope $^{f}$ & Membrane protein type 3 & 26.4 & 1 & 38 & 0.14 & 1 & 42 & 0.14 \\
\hline 51 & 282174088 & Envelope & Major envelope protein/Membrane protein type 3 & 26.5 & 30 & 1042 & 4.70 & 30 & 972 & 2.18 \\
\hline 57 & 282174094 & Capsid & Capsid protease-and-scaffolding protein & 78.0 & 9 & 345 & 0.45 & 8 & 328 & 0.43 \\
\hline 66 & 282174103 & Envelope & Membrane protein type 1 & 42.7 & 6 & 458 & 0.18 & - & - & - \\
\hline 67 & 282174104 & Envelope & $\begin{array}{l}\text { WBV spike protein/Major glycoprotein/Membrane } \\
\text { protein type } 1\end{array}$ & 152.9 & 25 & 948 & 0.43 & 15 & 577 & 0.26 \\
\hline 71 & 282174108 & Envelope & Membrane protein type 1 & 11.4 & 4 & 172 & 0.82 & 3 & 103 & 0.33 \\
\hline 78 & 282174115 & Envelope & Membrane protein type 3 & 16.9 & 4 & 146 & 0.23 & - & - & - \\
\hline 81 & 282174118 & $\begin{array}{l}\text { Tegument- } \\
\text { associated }\end{array}$ & & 51.5 & 7 & 226 & 0.63 & 1 & 56 & 0.07 \\
\hline
\end{tabular}


Table 4 Structural proteins of AngHV-1 as identified by 1D gel and 2D nanoLC-MS/MS (Continued)

\begin{tabular}{|c|c|c|c|c|c|c|c|c|c|c|}
\hline 83 & 282174120 & $\begin{array}{l}\text { Tegument- } \\
\text { associated }\end{array}$ & Cysteine protease domain/Large tegument protein & 376.8 & 166 & 6652 & 1.46 & 104 & 3870 & 0.71 \\
\hline 95 & 282174132 & Envelope & ISAV HA/Membrane protein type 1 & 41.6 & 54 & 2069 & 1.81 & 52 & 2256 & 1.48 \\
\hline 100 & 282174137 & Capsid & & 61.1 & 2 & 66 & 0.13 & 1 & 33 & 0.03 \\
\hline 103 & 282174140 & Tegument & & & - & - & - & - & - & - \\
\hline 104 & 282174141 & Capsid & Major capsid protein & 139.9 & 213 & 8402 & 5.33 & 104 & 4058 & 2.56 \\
\hline 108 & 282174145 & Envelope & ORF80 family & 108.2 & - & - & - & 1 & 33 & 0.06 \\
\hline 114 & 282174151 & $\begin{array}{l}\text { Tegument- } \\
\text { associated }\end{array}$ & & 20.7 & 28 & 852 & 3.64 & 13 & 550 & 1.27 \\
\hline 115 & 282174152 & Envelope & & & - & - & - & - & - & - \\
\hline 125 & 282174162 & Envelope & ORF109 family & & - & - & - & - & - & - \\
\hline 126 & 282174163 & Capsid & & 22.4 & 1 & 30 & 0.17 & & - & \\
\hline 128 & 282174165 & $\begin{array}{l}\text { Tegument- } \\
\text { associated }\end{array}$ & & 17.9 & 4 & 139 & 0.48 & 1 & 60 & 0.21 \\
\hline 129 & 282174166 & $\begin{array}{l}\text { Tegument- } \\
\text { associated }\end{array}$ & & 42.2 & 8 & 290 & 0.19 & 6 & 238 & 0.18 \\
\hline
\end{tabular}

${ }^{a}$ the ORF are ordered by number with the ORF only detected in the virion fractions presented in italics, ${ }^{b}$ location as determined in this paper, ${ }^{c}$ properties newly suggested in this paper are presented in italics,

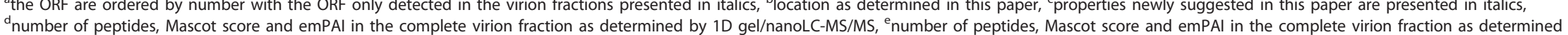
by $2 \mathrm{D}$ nanoLC-MS/MS, ${ }^{\mathrm{f}} \mathrm{AngHV}-1$ ORF49 was not detected in the envelope fraction and classified as an envelope protein only on the basis of predicted structural properties. 


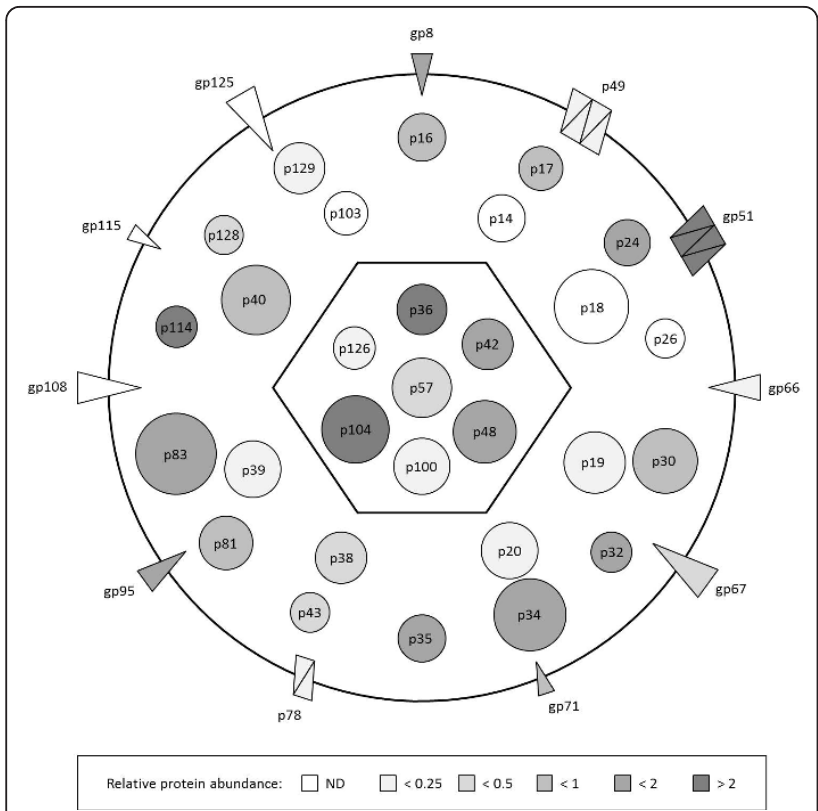

Figure 2 Schematic representation of the protein composition of mature extracellular AngHV-1 virions. The typical herpesvirus compartments are indicated as a hexagon (capsid), circle (envelope) and the space in between (tegument). The location of the structural proteins is indicated. Proteins identified as true tegument proteins directly surround the capsid, proteins identified as tegumentassociated proteins are located in the outer part of the tegument. The orientation of the envelope proteins indicates the number of transmembrane domains. The predicted protein mass is logarithmically indicated in size. The relative abundance (emPAl) as determined for the 1D gel/nanoLC-MS/MS analyses of complete virions is indicated in color intensity (see scale).

most efficient extraction and separation procedures for the current study, namely GC extraction followed by insolution trypsin digestion for the 2D nanoLC-MS/MS approach, and protein extraction with SDS followed by separation by SDS-PAGE and in-gel trypsin digestion for the 1D gel/nanoLC-MS/MS. Higher virion concentrations as well as additional analyses of separate virion fractions significantly contributed to the recovery of peptides derived from proteins present in low abundance.

When Davison and Davison identified the structural proteins of IcHV-1 in 1995, they found a total of 16 principal structural proteins [16]. We followed their capsid retrieval and virion fractionation techniques, confirmed by EM and SDS-PAGE, but used a more sensitive MS technique. The number of structural proteins found for AngHV-1 was significantly higher than the number found earlier for IcHV-1. Generally, the capsid retrieval and virion fractionation techniques worked well in combination with LC-MS/MS. Nevertheless, several highly abundant proteins showed some overspill in fractions where the proteins were not expected to be. This probably indicates that the virion fractionation techniques were not conclusive. In addition, it could be possible that proteins from which only one or two peptides were found are actually contaminating high abundant non-structural proteins, detected by the highly sensitive LC-MS/MS technique used.

Several observations support the accuracy of the final results of our approach. First, the number of proteins found in the different fractions was highly comparable to those determined by recent comprehensive characterization of extracellular herpes simplex virus type 1 and pseudorabies virus virions [23,25]. Second, all AngHV-1 sequence similarity based homologues of CyHV-3 structural proteins were found in AngHV-1 virions. Third, the proteins with a sequence predicted function were found in the expected fractions. Fourth, as for the low abundant proteins, several of these proteins have homologues in CyHV-3 and were accordingly detected in CyHV-3, which were purified using a different protocol [17]. Fifth, all proteins identified as envelope proteins showed many if not all of the basic characteristics of an envelope protein, whilst none of the other structural proteins showed a predicted transmembrane domain, and a signal peptide was predicted for only one non-envelope protein. Sixth, non-structural proteins such as proteins involved in DNA replication, DNA packaging or presumably secreted immunomodulatory proteins were not identified.

\section{Conclusions}

The identification and localization of the structural proteins of AngHV-1 in this study adds to the fundamental knowledge of members of the Alloherpesviridae family, especially for the known members of the related Cyprinivirus genus. The localization and putative function of the identified AngHV-1 structural proteins can now be extrapolated for homologous genes in other alloherpersviruses. In addition, the results presented give a first indication of the conservation of structural proteins within the Alloherpesviridae family. Conservation is high in the capsid fraction, limited in the tegument fraction and low in the envelope fraction. In this respect the Alloherpesviridae family resembles the Herpesviridae family, yet the evolutionary distance among fish and amphibian herpesviruses is significantly greater than among mammalian, bird and reptile herpesviruses. For AngHV-1 in particular, the results of this study will facilitate more directed functional characterization of proteins of interest. Moreover, this information is essential in further studies on the pathobiology of this virus, and will support the development of specific diagnostic tools and vaccines. 


\section{Additional material}

Additional file 1: Table S1: Host proteins associated with AngHV-1 virions as identified by $1 \mathrm{D}$ gel/nanoLC-MS/MS and 2D nanoLC-MS/

MS. This table contains the non-viral host-originating proteins identified in the 1D gel and 2D nanoLC-MS/MS analyses of complete virions by searching the peptides against a bony vertebrate database. Thirty and 15 host proteins were detected, respectively, with an overlap of 3 proteins, representing a total of 28 unique host proteins associated with AngHV-1 virions.

\section{Acknowledgements}

We are grateful to Ineke Roozenburg and Michal Voorbergen-Laarman (Central Veterinary Institute (CVI) of Wageningen UR) for technical support with cell and virus culture, to Lisette Ruuls (CVI) for EM sample preparations and guidance with the EM, and to Karel Riepema (CVI) for technical assistance with SDS-PAGE and gel staining. We thank Andrew Davison (MRCUniversity of Glasgow Centre for Virus Research) for useful comments on premature capsid purification and virion fractionation. This work was supported by a grant from the University of Liège (Crédit d'Impulsion) and a FRFC grant from the FNRS (2.4622.10).

\section{Author details}

${ }^{1}$ Central Veterinary Institute of Wageningen UR, P.O. Box 65, 8200 AB Lelystad, The Netherlands. ${ }^{2}$ Virology Division, Department of Infectious Diseases and Immunology, Faculty of Veterinary Medicine, Utrecht University, P.O. Box 80.165, 3508 TD Utrecht, The Netherlands. ${ }^{3}$ Proteomic and Microbiology (Pentagone), Interdisciplinary Center of Mass spectrometry (CISMa), University of Mons, Place du parc 20, B-7000 Mons, Belgium. ${ }^{4}$ Laboratory of Biochemistry, Wageningen University, Dreijenlaan 3, 6703 HA Wageningen, The Netherlands. Immunology-Vaccinology (B43b), Department of Infectious and Parasitic Diseases, Faculty of Veterinary Medicine, University of Liège, B-4000 Liège, Belgium.

\section{Authors' contributions}

SJvB designed the study, carried out the virus culture, virion purification \& fractionation, capsid isolation, SDS-PAGE, sample preparations for LC-MS/MS, bioinformatic analyses and drafted the manuscript. BL performed the 1D $\mathrm{gel} /$ nanoLC-MS/MS and 2D nanoLC-MS/MS measurements of complete virions, capsids and virion (including sample preparations), supervised by RW and coordinated by AV. OLMH headed the cell and virus cultures. SB assisted in the sample preparations for LC-MS/MS and performed the LCMS/MS analyses of the $U$ capsids, supervised by JJMV. BPHP, PJMR and AV advised on the study design and manuscript. MYE coordinated the study. All authors read and approved the final manuscript.

\section{Competing interests}

The authors declare that they have no competing interests.

Received: 15 June 2011 Accepted: 5 October 2011

Published: 5 October 2011

\section{References}

1. Davison AJ, Eberle R, Ehlers B, Hayward GS, McGeoch DJ, Minson AC, Pellett PE, Roizman B, Studdert MJ, Thiry E: The order Herpesvirales. Arch Virol 2009, 154:171-177.

2. Virus Taxonomy: 2009 Release. [http://www.ictvonline.org/virusTaxonomy. asp?version $=2009]$

3. Waltzek TB, Kelley GO, Alfaro ME, Kurobe T, Davison AJ, Hedrick RP: Phylogenetic relationships in the family Alloherpesviridae. Dis Aquat Organ 2009, 84:179-194.

4. Jakob NJ, Kehm R, Gelderblom HR: A novel fish herpesvirus of Osmerus eperlanus. Virus Genes 2010, 41:81-85.

5. Plumb JA: Channel Catfish Herpesvirus. In Viruses of Lower Vertebrates. Edited by: Ahne W, Kurstak E. Berlin: Springer-Verlag; 1989:198-216.

6. Haenen OLM, Way K, Bergmann SM, Ariel E: The emergence of Koi herpesvirus and its significance to European aquaculture. Bull Eur Ass Fish Pathol 2004, 24:293-307.
7. Michel B, Fournier G, Lieffrig F, Costes B, Vanderplasschen A: Cyprinid herpesvirus 3. Emerg Infect Dis 2010, 16:1835-1843.

8. Haenen OLM, Dijkstra SG, Tulden PW, Davidse A, van Nieuwstadt AP, Wagenaar F, Wellenberg GJ: Herpesvirus anguillae (HVA) isolations from disease outbreaks in cultured European eel, Anguilla anguilla in the Netherlands since 1996. Bull Eur Ass Fish Pathol 2002, 22:247-257.

9. Haenen OLM, Lehmann J, Engelsma MY, Stürenberg FJ, Roozenburg I, Kerkhoff S, Klein Breteler J: The health status of European silver eels, Anguilla anguilla, in the Dutch River Rhine Watershed and Lake IJsselmeer. Aquaculture 2010, 309:15-24.

10. Booy FP, Trus BL, Davison AJ, Steven AC: The capsid architecture of channel catfish virus, an evolutionarily distant herpesvirus, is largely conserved in the absence of discernible sequence homology with herpes simplex virus. Virology 1996, 215:134-141.

11. Pandey A, Mann M: Proteomics to study genes and genomes. Nature 2000, 405:837-846

12. Davison AJ: Channel catfish virus: a new type of herpesvirus. Virology 1992, 186:9-14.

13. Davison AJ, Cunningham C, Sauerbier W, McKinnell RG: Genome sequences of two frog herpesviruses. J Gen Virol 2006, 87:3509-3514

14. Aoki T, Hirono I, Kurokawa K, Fukuda H, Nahary R, Eldar A, Davison AJ, Waltzek TB, Bercovier H, Hedrick RP: Genome sequences of three koi herpesvirus isolates representing the expanding distribution of an emerging disease threatening koi and common carp worldwide. J Virol 2007, 81:5058-5065.

15. van Beurden SJ, Bossers A, Voorbergen-Laarman MH, Haenen OL, Peters S, Abma-Henkens MH, Peeters BP, Rottier PJ, Engelsma MY: Complete genome sequence and taxonomic position of anguillid herpesvirus 1. J Gen Virol 2010, 91:880-887.

16. Davison AJ, Davison MD: Identification of structural proteins of channel catfish virus by mass spectrometry. Virology 1995, 206:1035-1043.

17. Michel B, Leroy B, Stalin Raj V, Lieffrig F, Mast J, Wattiez R, Vanderplasschen A, Costes B: The genome of cyprinid herpesvirus 3 encodes 40 proteins incorporated in mature virions. J Gen Virol 2010, 91:452-462.

18. Varnum SM, Streblow DN, Monroe ME, Smith P, Auberry KJ, Pasa-Tolic L Wang D, Camp DG, Rodland K, Wiley S, Britt W, Shenk T, Smith RD, Nelson JA: Identification of proteins in human cytomegalovirus (HCMV) particles: the HCMV proteome. J Virol 2004, 78:10960-10966.

19. Kattenhorn LM, Mills R, Wagner M, Lomsadze A, Makeev V, Borodovsky M, Ploegh HL, Kessler BM: Identification of proteins associated with murine cytomegalovirus virions. J Virol 2004, 78:11187-11197.

20. Johannsen E, Luftig M, Chase MR, Weicksel S, Cahir-McFarland E, lllanes D, Sarracino D, Kieff E: Proteins of purified Epstein-Barr virus. Proc Natl Acad Sci USA 2004, 101:16286-16291.

21. O'Connor CM, Kedes DH: Mass spectrometric analyses of purified rhesus monkey rhadinovirus reveal 33 virion-associated proteins. J Virol 2006, 80:1574-1583.

22. Dry I, Haig DM, Inglis NF, Imrie L, Stewart JP, Russell GC: Proteomic analysis of pathogenic and attenuated alcelaphine herpesvirus 1.J Virol 2008, 82:5390-5397.

23. Kramer T, Greco TM, Enquist LW, Cristea IM: Proteomic characterization of pseudorabies virus extracellular virions. J Virol 2011, 85:6427-6441.

24. Zhu FX, Chong JM, Wu L, Yuan Y: Virion proteins of Kaposi's sarcomaassociated herpesvirus. J Virol 2005, 79:800-811.

25. Loret S, Guay G, Lippe R: Comprehensive characterization of extracellular herpes simplex virus type 1 virions. J Virol 2008, 82:8605-8618.

26. van Nieuwstadt AP, Dijkstra SG, Haenen OL: Persistence of herpesvirus of eel Herpesvirus anguillae in farmed European eel Anguilla anguilla. Dis Aquat Organ 2001, 45:103-107.

27. Chen SN, Ueno Y, Kou GH: A cell line derived from Japanese eel (Anguilla japonica) kidney. Proc Natl Sci Counc Repub China B 1982, 6:93-100.

28. Gilad O, Yun S, Andree KB, Adkison MA, Zlotkin A, Bercovier H, Eldar A, Hedrick RP: Initial characteristics of koi herpesvirus and development of a polymerase chain reaction assay to detect the virus in koi, Cyprinus carpio koi. Dis Aquat Organ 2002, 48:101-108.

29. Ince IA, Boeren SA, van Oers MM, Vervoort JJ, Vlak JM: Proteomic analysis of Chilo iridescent virus. Virology 2010, 405:253-258.

30. Mastroleo F, Leroy B, Van Houdt R, s' Heeren C, Mergeay M, Hendrickx L, Wattiez R: Shotgun proteome analysis of Rhodospirillum rubrum $\mathrm{S} 1 \mathrm{H}$ : 
integrating data from gel-free and gel-based peptides fractionation methods. J Proteome Res 2009, 8:2530-2541.

31. Ishihama Y, Oda Y, Tabata T, Sato T, Nagasu T, Rappsilber J, Mann M: Exponentially modified protein abundance index (emPAl) for estimation of absolute protein amount in proteomics by the number of sequenced peptides per protein. Mol Cell Proteomics 2005, 4:1265-1272.

32. CBS Prediction Servers. [http://www.cbs.dtu.dk/services/]

33. Krogh A, Larsson B, von Heijne G, Sonnhammer EL: Predicting transmembrane protein topology with a hidden Markov model: application to complete genomes. J Mol Biol 2001, 305:567-580.

34. Emanuelsson $\mathrm{O}$, Brunak S, von Heijne G, Nielsen H: Locating proteins in the cell using TargetP, SignalP and related tools. Nat Protoc 2007, 2:953-971.

35. Gupta R, Jung E, Brunak S: Prediction of N-glycosylation sites in human proteins.[http://www.cbs.dtu.dk/services/NetNGlyc/abstract.php].

36. Julenius K, Molgaard A, Gupta R, Brunak S: Prediction, conservation analysis, and structural characterization of mammalian mucin-type Oglycosylation sites. Glycobiology 2005, 15:153-164.

37. Gibson W, Roizman B: Proteins specified by herpes simplex virus. 8. Characterization and composition of multiple capsid forms of subtypes 1 and 2. J Virol 1972, 10:1044-1052.

38. Perdue ML, Cohen JC, Kemp MC, Randall CC, O'Callaghan DJ: Characterization of three species of nucleocapsids of equine herpesvirus type-1 (EHV-1). Virology 1975, 64:187-204.

39. Perdue ML, Cohen JC, Randall CC, O'Callaghan DJ: Biochemical studies of the maturation of herpesvirus nucleocapsid species. Virology 1976, 74:194-208.

40. Mettenleiter TC, Klupp BG, Granzow H: Herpesvirus assembly: an update. Virus Res 2009, 143:222-234.

41. Newcomb WW, Trus BL, Booy FP, Steven AC, Wall JS, Brown JC: Structure of the herpes simplex virus capsid. Molecular composition of the pentons and the triplexes. J Mol Biol 1993, 232:499-511.

42. Rosenkranz D, Klupp BG, Teifke JP, Granzow H, Fichtner D, Mettenleiter TC, Fuchs W: Identification of envelope protein pORF81 of koi herpesvirus. J Gen Virol 2008, 89:896-900.

43. Muller A, Markussen T, Drablos F, Gjoen T, Jorgensen TO, Solem ST, Mjaaland S: Structural and functional analysis of the hemagglutininesterase of infectious salmon anaemia virus. Virus Res 2010, 151:131-141.

44. Schutze H, Ulferts R, Schelle B, Bayer S, Granzow H, Hoffmann B, Mettenleiter TC, Ziebuhr J: Characterization of White bream virus reveals a novel genetic cluster of nidoviruses. J Virol 2006, 80:11598-11609.

45. Mocarski ES: Comparative analysis of herpesvirus-common proteins. In Human Herpesviruses: Biology, Therapy, and Immunoprophylaxis. Edited by: Arvin A, Campadelli-Fiume G, Mocarski E, Moore PS, Roizman B, Whitley R, Yamanishi K. Cambridge: Cambridge University Press; 2007:

46. Guo H, Shen S, Wang L, Deng H: Role of tegument proteins in herpesvirus assembly and egress. Protein Cell 2010, 1:987-998.

47. Makarova KS, Aravind L, Koonin EV: A novel superfamily of predicted cysteine proteases from eukaryotes, viruses and Chlamydia pneumoniae. Trends Biochem Sci 2000, 25:50-52.

48. Newcomb WW, Brown JC: Structure and capsid association of the herpesvirus large tegument protein UL36. J Virol 2010, 84:9408-9414.

49. Davison AJ: Comparative analysis of the genomes. In Human Herpesviruses: Biology, Therapy, and Immunoprophylaxis. Edited by: Arvin A, Campadelli-Fiume G, Mocarski E, Moore PS, Roizman B, Whitley R, Yamanishi K. Cambridge: Cambridge University Press: 2007:

50. McGeoch DJ, Rixon FJ, Davison AJ: Topics in herpesvirus genomics and evolution. Virus Res 2006, 117:90-104.

doi:10.1186/1297-9716-42-105

Cite this article as: van Beurden et al: Identification and localization of the structural proteins of anguillid herpesvirus 1 . Veterinary Research 2011 42:105.

\section{Submit your next manuscript to BioMed Central and take full advantage of:}

- Convenient online submission

- Thorough peer review

- No space constraints or color figure charges

- Immediate publication on acceptance

- Inclusion in PubMed, CAS, Scopus and Google Scholar

- Research which is freely available for redistribution

Submit your manuscript at www.biomedcentral.com/submit
Biomed Central 